\title{
İstanbul'un Düğün Turizmi Potansiyelinin Değerlendirilmesi ${ }^{\star}$
}

\section{Evaluation of Istanbul's Wedding Tourism Potential}

\author{
Dr. Öğr. Üyesi Bayram KANCA \\ Giresun Üniversitesi \\ Turizm Fakültesi, Giresun, Türkiye \\ E-posta: bayram.kanca@giresun.edu.tr
}

\author{
Prof. Dr. Kamil UNUR \\ Mersin Üniversitesi \\ Turizm Fakültesi, Mersin, Türkiye \\ E-posta: kunur@yahoo.com
}

\section{Öz}

$\mathrm{Bu}$ çalışma, İstanbul'un düğün turizm pazarındaki mevcut durumunu, düğün turizm olanaklarını, ön plana çıkarılması gereken özelliklerini, rakiplerini, pazarda sahip olduğu fırsatları, potansiyel pazarlarını, bu pazarlardaki payının nasıl arttırılabileceğini ve dünyada bilinen, tanınan ve tercih edilen bir düğün destinasyonu markasına sahip olup olamayacağını tespit etmek amacıyla yapılmıştır. Tarama modeli, keşfedici araştırma yaklaşımı ve nitel yöntem kullanılarak destinasyon paydaşlarının görüşleri doğrultusunda İstanbul' un düğün turizmi potansiyeli değerlendirilmiştir. Araştırma verileri yapılandırılmış mülakat tekniğiyle toplanmış olup, toplanan verilere içerik analizi uygulanmıştır. İstanbul Boğazı' nın ve diğer doğal güzellikler ile kültürel miras öğelerinin, Ortadoğu başta olmak üzere tüm dünyaya, özelikle de üst gelir grubuna, romantizm ve farklılık arayışında olan çiftlere pazarlanabileceği ve düğün turizmi gibi yeni bir ürünle turizm sektöründe ek gelir kaynağı yaratılabileceği sonucuna varılmıştır.

Anahtar Kelimeler: Düğün turizmi, İstanbul, Destinasyon Düğünleri, Yurtdışı Düğünleri

\section{Abstract}

The aim of the study is to determine the present situation of Istanbul in the wedding tourism market, wedding tourism facilities, which features should be foregrounded, opportunities, competition, potential markets and how their share in these markets can be increased, and whether they will have a known and preferred wedding destination brand in the world. Using the scanning model, exploratory research approach and qualitative method, the potential of Istanbul's wedding tourism was evaluated in line with the views of destination stakeholders. The research content was collected through structured interview technique and content analysis was applied to the collected data. It is concluded that the Bosphorus, other natural beauties and cultural heritage items can be marketed to the world, primarily the Middle East, especially to the upper income group, to couples seeking romance and difference and an additional source of income can be created in the tourism sector with a new product such as wedding tourism.

Key Words: Wedding tourism, İstanbul, Destination Weddings, Abroad weddings 


\section{Giriş}

Ülkeler uluslararası turizm gelirlerinden daha fazla pay alabilmek için turizm ürünü yelpazelerini genişletmeye çalışmaktadırlar. Bu ülkelerden bir tanesi de Türkiye'dir. Akdeniz ülkesi olması nedeniyle Türkiye'nin en önemli turizm ürünlerinden bir tanesi deniz-kum-güneş üçlemesidir. Ancak bir taraftan Türk turizminin bu üründe belirli bir doygunluğa ulaşması ve bu ürünün diğer turizm ürünlerine kıyasla ucuz olması, diğer taraftan uluslararası turizm talebinde yaşanan değişimler nedeniyle Türkiye turizm ürünü yelpazesini genişletmeye çalışmaktadır. Çünkü Türkiye'nin uluslararası turizm pazarından aldığı payı artırabilmesi pazara sunduğu turizm ürünü yelpazesini çeşitlendirmesiyle mümkün olabilecektir. Soruna sayılarla bakıldığında, yıllar içerisinde Türkiye'ye gelen turist sayısı ve bu turistlerden elde edilen toplam gelir artsa da, turist başına yapılan harcama da belirgin bir değişim yaşanmadığı hatta olumsuz anlamda küçük düşüşler yaşandığı görülmektedir. Örneğin, Türkiye'nin turizm geliri 2005 yılında 20 milyar 322 milyon ABD Doları, 2010 yılında 24 milyar 930 milyon dolar, 2015 yılında 31 milyar 464 milyon dolar, 2019 yılında ise 34 milyar 520 milyon; kişi başı harcama ise, 2005'te 842 dolar, 2010 yılında 755 dolar, 2015'te 756 dolar, 2019 yılında ise, 666 dolar olmuştur (TUIK, 2020). Bu durum Türkiye'nin özellikle kişi başı turist harcamasını artırabilmesi için daha çok harcama potansiyeli olan turizm ürünlerine yönelmesini gerektirmektedir.

Etkinlikler, turizmi geliştiren ve destinasyon pazarlamasında son yıllarda güçlü bir talep yaratıcısı haline gelerek, ulaştırma, konaklama, eğlence ve diğer işletmelere dikkat çekici bir katkı sağlamaktadır (Karagöz, 2006: 4). Ayrıca turistik destinasyonlar için çeşitli ekonomik, sosyal, çevresel hedeflere ulaşılmasına katkı sağlayan önemli araçlardır. Turizm ve etkinlikler arasındaki ilişkinin en önemli unsuru etkinliklerle ilişkili imajın destinasyona transfer edilmesi ile kentlerdeki önemli doğal ve fiziksel çekiciliklerin harekete geçirilmesi ve etkinliklerin destinasyon markasını güçlendirme, destekleme ve değiştirmeye olan etkisidir (Jago ve diğ., 2002: 130). Etkinlikler, turizm çekiciliği olarak, bir destinasyonda uzun süreli kalışlar için ziyaretçilere neden oluştururlar ve aynı zamanda yerel turistleri bölgede tutar ve bölge içinde turizm harcamalarını yapmayı da sağlarlar (Derrett, 2004: 39). Destinasyonlara olan turizm talebi, farklı zamanlara olduğu gibi farklı yerlere de dağıtılabilir. Etkinliklerin çekiciliği, bireylere günlük yaşamları kapsamında var olmayan fırsatlar sağlayarak sundukları benzersiz deneyimlerden kaynaklanmaktadır (Getz, 1990: 129).

Destinasyonlarda bulunan turizm kaynaklarını, imaj oluşturucuları ve diğer destinasyon kaynaklarını bir turizm çekiciliği oluşturmak ve arttırmak için sistematik olarak planlanan, geliştirilen ve pazarlanan etkinlikler, etkinlik turizmi olarak tanımlanmaktadır (Getz, 1997: 16). Etkinlik turizmi, bir destinasyonun pazarlamasında motive edici bir faktör ve bir pazarlama aracı olarak ortaya çıkmaktadır (Ritchie, 1997: 51). Etkinlik turizmi son yıllarda özel ilgi turizmi çeşitleri arasında turizm endüstrisinin önemli ögelerinden biri haline gelmiştir (Getz, 1997: 16; Crompton ve McKay, 1997: 429; Arcodia ve Robb, 2000: 158). 20. yüzyılda dünya genelinde birçok özel etkinlik kutlanılmaya başlanmıştır (Getz, 2008: 410).

Etkinlik türüne bağlı olarak hayat boyunca belki yalnızca bir kez katılma fırsatı sunulan etkinlikler bulunmaktadır (dünya kupası, olimpiyatlar vb.). Bu durum sınırlı katıım fırsatını elde etmiş olanların gözünde etkinliğe katılmayı benzersiz veya özel kılmaktadır. Temalarına göre özel etkinliklerin altında sınıflandırılan düğünler (Getz, 1997: 7), Shone ve Parry (2004: 4) tarafından kişisel etkinliklerin içinde sınıflandırılmıştır. 
Türkiye'de bir çift düğün mekânına ortalama 35 bin TL harcarken, ortalama bir düğünün 55 bin TL'ye mal olduğu belirtilmektedir (Düğün, 2015; Dünya, 2015). Özellikle İstanbul'da Boğaz kıyısında yapılan dizi çekimleri Hint ve Arap zenginlerin ilgisini çekmekte ve düğün organizasyonlarını daha önce Amerika, İtalya ve Fransa gibi ülkelerde yapan yabancıların İstanbul'a gelmesine neden olmaktadır. Türkiye'de 2012 yılında 50 tanesi 3-5 milyon dolarlık organizasyonlar olan toplam 350 yabancı düğün organize edilmiştir (Hürriyet, 2012 ). Yine Çırağan Sarayı'nda, bir yılda 100'ün üzerinde düğün gerçekleşmekte ve bunların 5 'te 1 'ini yabancıların düğünleri oluşturmaktadır (CNN Türk, 2010). Haber3'e (2011) göre Rusya'da çok ünlü bir düğün magazini şirketinin internet sitesinde (www.wedding-magazine.ru), Türkiye, dünyada düğün turizmi yapılacak ülkeler arasında 7. sırada gösterilmektedir. Aynı haberde, düğün organizatörlerine ve kıyafet tedarikçilerine göre yılda en az 3 bin turist çiftinin Türkiye'de düğün yaptığı belirtilmiştir.

Bir destinasyondaki turizm ürünlerinin çeşitlendirmesinde genellikle turistlerin tercihlerindeki değişmeler, rekabet gibi çevresel faktörler etkili olabilmektedir (Demir ve Demir, 2004). Bu nedenle, turistin değişikliğe uğrayan gereksinimlerini ve davranışlarını belirlemek ve bu gereksinimler doğrultusunda turizm ürünleri üretmek veya çeşitlendirmeye gitmek gerekmektedir. Bu sürece katkı verecek unsurlardan birisi de alanla ilgili bilimsel araştırmaların yapılmasıdır. Bu çalışma ile İstanbul'da düğün turizminin gelişimine önemli katkılarda bulunulabileceği düşünülmektedir. Böylece İstanbul sahip olduğu olanakları ve eşsiz doğasını kullanarak, düğün turizmi pazarında başarılı olabilir.

\section{Düğün Turizmi}

Düğün, evlenme veya sünnet için yapılan tören, eğlence ya da cemiyet, bir olayı kutlamak için yapılan tören ya da büyük eğlence olarak tanımlanmaktadır (TDK, 2020). Günümüzde her düğün büyük eğlencelerin yapıldığı bir etkinlik olmaktan çıkmış durumdadır. Nitekim Schumann ve Amado (2010: 173) düğünü, aile üyelerinin evlenen çiftlerin bu özel durumunu kutlamak için bir araya geldikleri özel bir etkinlik olarak tanımlamaktadır. Düğün turizmi (wedding tourism) ise, evlenen çiftlerin sürekli yaşadığı yerin dışında başka bir kentte ya da ülkede gerçekleştirecekleri eğlence ya da düğün törenini ve bu törene katılmak isteyenlerin yaptıkları seyahati kapsayan turist akışı olarak da tanımlanmaktadır (Daniels ve Loveless, 2013: 87). De Witt (2006: 9) düğün turizmini, evlenen çiftlerin ve düğüne katılan misafirlerin ulaşımını, konaklamasını, törendeki ikramları ve eğlenceyi kapsayan bir etkinlik olarak tanımlamaktadır. Düğün turizmi yerine yazında destinasyon düğünü (destination wedding), yurtdışı düğünü (wedding abroad) gibi kavramlar da kullanılmaktadır. Destinasyon düğünü, çiftlerin memleketleri dışında yaptıkları düğünlerdir (Schumann ve Amado, 2010: 176). Yurtdışı düğünü ise, evlenmek veya bir başkasının düğün törenine katılmak için yapılan uluslararası seyahatler olarak tanımlanmaktadır (Major ve diğ., 2010: 249). Tanımlamalara bakıldığında bu üç kavram da aynı anlamda kullanılmaktadır. Türkiye'de ise, bu olay sektördeki öncü işletmeler tarafından "evlilik turizmi" olarak da lanse edilmektedir. "Evlilik turizmi" her ne kadar uygulamada kullanılsa da; gerek sektörde, gerek basında, gerekse yazında düğün turizmi kavramı kabul görerek kullanımı artmaktadır (Unur ve diğ., 2017: 153).

Major ve diğ., (2010: 252) göre düğün turizmindeki ana pazar bölümleri, ilk defa evlenenlerin düğünleri, yeniden evlilikler, eşcinsel evliliklerin yasak olduğu ülkelerden yasal olanlara düğün için yapılan seyahatler ve yurtdışındaki nikâh tazeleme törenleri oluşturmaktadır. Bu düğünlerin bileşenleri ise, çiftler, törenin konukları, düğüne katılan herkesin ulaşımı, konaklaması, düğün töreni, resepsiyon, eğlence hizmetleri, 
yurtdışında düğün için resmi konularda danışmanlık hizmetleri, çiftlerin ve konukların düğün kıyafetleri ile diğer düğün ekstralarından oluşmaktadır (Wolf ve diğ., 2005: 192; De Witt, 2006: 69; Silvers, 2012: 6). Dünyada düğün turizmine katılan turistlerin büyük bölümü, Almanya, Amerika Birleşik Devletleri, Fransa, İngiltere, İskandinavya ve İtalya vatandaşlarıdır. En popüler dügün turizmi destinasyonlar ise, Hawaii, İtalya, Karayipler, Kıbrıs, Maldivler, Mauritius, Meksika ve Sri Lanka'dır (Poon, 2009: 3). Yazında düğün turizmine katılmakla ilgili üç temel motivasyona vurgu yapılmaktadır. Bunlar; geleneksel düğünlerin yurtdışı düğünlerine kıyasla çok pahalı olması sebebiyle çiftlerin fazla para harcamak istememeleri; güzel bir havada, güneşli bir günde düğün yapmayı garanti altına alma arzusu; benzersiz bir yerde unutulmaz bir düğün gerçekleştirme isteği olarak belirlenmiştir (Kim ve Agrusa, 2005: 901; Major, ve diğ., 2010: 253).

Çiftlerin ve konuklarının bölgeye seyahatlerinden kaynaklanan bir dizi ekonomik fayda sağlanan düğün turizmi destinasyonlarında hem turizm sektör bileşenlerine hem de yan sektörlere katkıda bulunulmaktadır. Çiftlerin düğün turizmi destinasyonu seçimlerinde ise, karar verme süreçlerini etkileyen faktörler arasında doğallık ve manzara önemli bir yer tutmaktadır (Kim ve Agrusa, 2005: 901).

Lau ve Hui (2010) Hong Kong'da yaptıkları bir çalışmada çiftlerin düğün mekânı seçimlerinde işletmenin çalışanlarının tutumu, hijyeni, yiyecek ve içeceklerinin kalitesi ile fiyatları en önemli kriterler olarak belirtmişlerdir. Düğün mekânı seçimine ilişkin 25 kriterin belirlendiği çalışmada mekân dizaynına, dekorasyonuna, mekânın kullanılabilirliğine de katılımcılar önem atfetmiştir. Çiftlerin ilk izlenimi, kişisel tercihleri ve deneyim düzeyleri içsel faktörler olarak; mekânın ünü, ürün paketinin çekiciliği, satışçının etkisi de dışsal faktörler olarak önemli bulunmuştur. Hong Kong'da yıllık 755 milyon dolarlık pazar büyüklüğüne sahip olduğu belirtilen düğün turizmi için müşterilerin istek ve beklentilerini bilmenin işletmeler için önemi vurgulanmış, işletmelere müşteri odaklı bir yaklaşımı benimsemeleri tavsiye edilmiştir.

Kim ve Kim (2013) düğün turizm pazarında Kore düğün sektörünün SWOT analizini yaptıkları çalışmada Kore düğün sektöründeki ekonomik bunalımı atlatmak için düğün turizminin geliştirilmesi ve Japon pazarında bu ürünün değerlendirilmesi önermişlerdir. Japonya ve Kore arasındaki feribot seferleri ve gemi düğünlerinin üzerinde durulduğu çalışmada gemi düğünü ve bağlantılı olabilecek ürünler değerlendirilmiştir. Japonya'daki geleneksel düğün seremonilerinin pahalılığı ve Kore'nin nispeten daha ucuz olduğuna değinilmiştir. Çalışmada, Japonya ve Kore arasındaki feribotlarda düğün töreni ve Kore'de balayını içeren bütünleşik bir ürün önerisi üzerinde durulmuştur. Japonya ve Kore fiyat karşılaştırmalarının yapıldığı çalışmada tüketicilerin zaten yapacakları balayı seyahati masraflarına ek olarak ödeyecekleri Japonya'nın çok altında fiyatlarla hem düğün hem de balayı yapabilecekleri belirtilmiştir. Lüks segment tüketiciler için ise otel düğün paketleri önerilmiştir. Ayrıca ABD'de balayı pazarının büyüklüğüne değinilerek; bu pazar için balayı paketleri önerilmiş, düğün turizmi ile bağlantılı diğer ürünlerin (fotoğraf, kıyafet, kuaför, wellness hizmeti vb.) pazarlanmasıyla ilgili de öneriler geliştirilmiştir. Ağırlıklı olarak tüketiciler için maliyet yönlü bir değerlendirmenin yapıldığı çalışmada gemi düğünlerinin farklılık yaratacağına da değinilmiştir.

Durinec (2013) düğün turistlerinin profilini çıkardığı çalışmada; düğün turizminin "uzun ömürlü güzel anılar" ile gelecek için potansiyel müşteri tabanı yarattığını ve hem çiftlerin hem de dügüne katılanların tekrar ziyaret etme niyetlerinin yüksek olduğunu belirlemiştir. Araştırmacı bu turizm türünün müşterilerle uzun süreli iliş̧i yaratmaya katkı sağladığını öne sürmüştür. Çalışmada bu turizm türüne orta yaşlı ve yaşlı çiftlerin daha çok katıldığı, nikâh tazeleme, ikinci balayı gibi bazı romantik olayların 
tüketildiğine değinilmiştir. Düğün turizmi paydaşları arasında bir ağ oluşturulması, işbirliğinin sağlanması, tanıtımın ortak bir çatı altında yapılması, düğün turizminde markaların yaratılması, ürün standartların oluşturulması, ürün farklılaştırma ile değişik seçenekleri barındıran çeşitli paketlerin sunulması ile daha çok müşterinin çekilebileceğine değinilmiştir.

Rogerson ve Wolfaardt, (2016: 11) dügün turizmini yerli ya da uluslararası tüketicilerin mekân seçiminde "yer"in önemli olduğu bir etkinlik turizmi biçimi olarak değerlendirmiştir. Cape Town'da, Johannesburg ve Durban'ın çevresi ile Cape Winelands'deki düğün mekânları, coğrafi olarak tercih edilen yerler olarak belirtilirken; hem kentsel hem de kırsal çevrelerdeki doğal güzelliklerin bu tercihlerde etkili olduğu belirtilmiştir.

İtalya'ya giden Çinli düğün turistlerinin profilini inceleyen La Ragione, (2019:77) Çinli Y Kuşağını doğasever, bozulmamış manzaralarla ve ekolojik sorunlara ilgilenen bireyler olarak tarif etmiştir. Çinli çiftlerin önceleri Güney Doğu destinasyonları, özellikle Bali ve Phuket gibi adalarla ilgilenirken son zamanlarda İtalya gibi kültürel birikimi olan Avrupa ülkelerine yöneldikleri tespit edilmiştir. 2017 yılı sonunda, İtalya'da 7147 destinasyon düğünü gerçekleştiği, 2016'ya göre \% 4,7 azalmasına rağmen gelirlerin \% 2,3 artışla yaklaşık olarak toplam 368 milyon avro olduğu ve İtalya'ya giden toplan düğün turist sayısının 336232 kişi olduğu belirtilmiştir. İtalya'da giden düğün turistlerinin \% 24,4'ü ABD, \% 21,9'u İngiltere ve \% 5,9'u ise Çin vatandaşıdır. Çinli çiftler İtalya'da evlenmek için genellikle tüm dünyada bilinen sanatsal ve tarihi şehirleri seçmektedirler ve tercih edilen İtalyan şehirleri ve bölgeleri arasında ilk sırada çoğunlukla Toskana Amalfi sahilleri, Napoli ve Campania bölgesi yer almaktadır. Çalışmada destinasyon düğünleri üç kategoriye ayrılmıştır. Bunlar; \% 76,2 ile standart düğünler (toplam cirosu yaklaşık 137 milyon avro), \% 19,4 ile lüks düğünler (toplam cirosu yaklaşık 178 milyon avro) ve \% 4,4 ile birinci sınıf lüks düğünlerdir (toplam cirosu yaklaşık 70 milyon avro).

İstanbul son yıllarda Türk dizileriyle birlikte turizmde artan bir ilgiye sahiptir. Özellikle İstanbul Boğaz kıyısında yapılan dizi çekimleri Hintli ve Arap zenginlerin ilgisini çekmekte, düğün organizasyonları için daha önce Amerika, Fransa ve İtalya gibi ülkeleri tercih eden bu kişiler artık düğün için İstanbul'a gelmektedir. 2012 yılı için 350 civarında yabancı düğün organize edilirken; bu düğünlerin yaklaşık 50'si ise 3-5 milyon dolarlık büyük organizasyonlardır. İstanbul'un tarihi geçmişi, konumu, dünyadaki bilinirliği dikkate alındığında iyi bir pazarlama faaliyeti yapıldığı takdirde düğün turizmi pazarından büyük bir pay alması muhtemeldir. Dünyada en çok düğün yapılan iki şehirden biri olması her ne kadar kalabalık bir nüfusa sahip olmasından kaynaklansa da, bu durum düğün turizmi için gerekli arz kaynaklarına da sahip olduğunu göstermektedir. 2010 yılında Dünya Kültür Başkentlerinden biri olarak seçilen İstanbul, 2011'de ve 2013'te yapılan iki ayrı çalışmada yüksek değerli bir marka şehir olarak nitelendirilmiştir (Ijpar, 2011; Uysal, 2013). Marka değerine en yakın Roma ve Atina şehirlerinin belirtildiği İstanbul, "İmparatorluklar Başkenti", "Konuksever", "Medeniyetler Başkenti", "Dinler Başkenti", "Doğu ve Batı arasındaki şehir", "Hoşgörü" gibi kelimeler ile tarif edilmiştir (İpar, 2011; Uysal, 2013). İstanbul'un düğün turizmi pazarında başarılı bir tanıtım faaliyetinin yapılabilmesi için sahip olduğu bu doğal imajının kullanılabileceği düşünülmektedir. Özellikle Türk dizileriyle gelişen ilgi de düşünüldüğünde İstanbul dünya jet sosyetesinin düğün destinasyonu olmaya aday bir şehir olabilir.

\section{Yöntem}

Çalışmanın amacı, İstanbul'un düğün turizm pazarındaki mevcut durumunu, düğün turizm olanaklarını, hangi özelliklerinin ön plana çıkarılması gerektiğini, düğün 
turizminde sahip olduğu fırsatları, rakiplerini, potansiyel pazarlarını, bu pazarlardaki paylarının nasıl arttırılabileceğini ve dünyada bilinen, tanınan ve tercih edilen bir düğün destinasyonu markasına sahip olup olamayacağını tespit etmektir. Turizm sektörüne, bağlantılı olduğu iş kollarına, ülke ve şehrin tanıtımına katkısı düşünüldüğünde; bu çalışma ile bu turizm ürününün bilimsel yöntemlerle tüm yönleriyle incelenecek olması, karar verici makamda olanlara ve sektör temsilcilerine gerek bu turizm ürününü değerlendirmeleri gerekse turizm pazarında doğru kararlar vermeleri konusunda olumlu katkı sağlayacaktır. Sağlayacağı bu katkılardan dolayı bu çalışmanın yapılmasının önemli olduğu düşünülmektedir.

Çalışmada tarama modeli, keşfedici araştırma yaklaşımı ve nitel yöntem benimsenmiştir. Çalışma verilerini toplamak amacıyla yazındaki düğün turizmi çalışmalarından (De Witt, 2006; Major ve diğ., 2010; Lau ve Hui, 2010; Nguyen, 2011; Deng, 2013; Seebaluck ve diğ., 2015; Del Chiappa ve Fortezza, 2016; Bertella, 2015) faydalanılarak 13 açık ve kapalı uçlu sorulardan oluşan görüşme formları hazırlanmıştır. Araştırmada yanıtı aranan temel sorular şu şekildedir: İstanbul'un düğün turizmi kapsamında güçlü ve zayıf yönleri nelerdir? İstanbul'un düğün turizmi kapsamında sahip olduğu fırsatlar ve bu destinasyon için tehditler nelerdir? İstanbul destinasyonunda düğün turizmi nasıl geliştirilebilir? Hazırlanan görüşme formlarına Mersin Üniversitesi Turizm Fakültesi öğretim üyelerinin görüşleri doğrultusunda son şekli verilmiştir. Olasılığa dayalı olmayan örnekleme yöntemlerinde kasti (kararsal) örnekleme yöntemi ya da diğer adıyla amaçsal (amaçlı) örnekleme (purposive/purposeful sampling) yöntemi seçilmiştir. Bu yöntem, çalışmanın amacına uygun olarak bilgi açısından zengin, araştırma sorularına cevap verebilecek kişilerin, durumların seçilerek derinlemesine araştırma yapılmasına olanak tanımaktadır (Altunışık ve diğ., 2012: 71; Büyüköztürk ve diğ., 2012: 90). Son şekli verilen görüşme formları; 2017 yılı Ocak-Aralık aylarında İstanbul'da düğün turizminin paydaşları olarak tespit edilen düğün organizasyonu yapılan otellerin yöneticilerine, düğün turizmi organizatörlerine, turizm akademisyenlerine ve Kültür ve Turizm İl Müdürlerine ve belediyelere uygulanmıştır. Bu çalışma, Kanca' nın (2018) Mersin Üniversitesi Sosyal Bilimler Enstitüsü'nde 9 Şubat 2018 tarihinde kabul edilen doktora tezinden üretildiği için Etik Kurul izni ile ilgili düzenlemeler yapılmadan önce verileri toplanmıştır. Bu sebeple Etik Kurul İzin Formu yerine ilgili dönemde uygulamada olan Tez Etik Beyan Formu dergi yönetimine sunulmuştur. Veri toplama sürecinde yaşanan çeşitli sıkıntılar (randevu vermeme, cevap vermeme, sınırlı sayıda organizatör olması vb.) sebebiyle sürecin sonunda, İstanbul'da 2 düğün organizatöründen, 15 otel yöneticisinden, 15 turizm akademisyenden ve 1 turizm il müdürlüğünden olmak üzere 33 kullanılabilir görüşme elde edilmiştir. Toplanan verileri açıklayabilecek kavramlara ve ilişkilere ulaşmak için bu verilerin önce kavramsallaştırılması, daha sonra da ortaya çıkan kavramlara göre mantıklı bir biçimde düzenlenmesi ve buna göre veriyi açıklayan temaların saptanması amacıyla verilere içerik analizi yapılmıştır (Altunışık ve diğ., 2012: 324). Çalışmada, yazındaki ilgili çalışmalar dikkate alınarak kodlamalar yapılmış ve bu bağlamda çeşitli temalara ulaşımıştır. Daha sonra veriler temalara göre gruplanmış ve uygun olduğu durumlarda veriler sayısal hale getirilerek sunulmuştur. Bilimsel çalışmaların belirli bir olgu ya da belirli zaman dilimlerindeki süreçleri konu alması sebebiyle çalışmanın veri toplama süreci 2017 yılı ile sınırlıdır. Ulaşılmış olan paydaş sayısı, araştırmanın maddi kısıtları ve paydaşların erişilebilirliği de çalışmanın diğer sınırlılıklarıdır.

\section{Bulgular}

İstanbul'da 2 düğün organizatörü, 15 otel yöneticisi, 15 turizm akademisyeni ve 1 turizm il müdürlüğü olmak üzere 33 düğün turizm paydaşına ulaşılmıştır. İstanbul'da 
katılımcıların \%51,52'si özel sektör, \%48,48'i kamu çalışanıdır. Özel sektör çalışanlarına ulaşılırken çalıştıkları işletmede konuyla ilgili yönetici/karar alıcı pozisyondaki kişiler olmaları göz önünde bulundurulmuştur. Kamu da ise, turizm alanında çalışan akademisyenler ve görev tanımı; "Il'deki turizm talep ve türlerinde meydana gelen değişme ve gelişmelerle uyumlu turizm politikalarının oluşturulmasına ve yatırımların yönlendirilmesine elverişli her türlü araştırmaları yapmak ve yaptırmak" olan turizm il müdürleri yer almaktadır. Düğün turizminin ilk kademe uygulayıcıları olmalarına rağmen düğün organizatörlerinin sayısının az olmasının sebebi, yeni bir ürün olması nedeniyle düğün turizmi tanımına uygun düğünler yapan az sayıda organizatör olması ve katılım isteği gösteren yalnızca 2 organizatöre ulaşılabilmesidir.

İstanbul'da düğün turizmiyle ilgili mevcut durumun değerlendirilmesi; turizm sektöründeki uygulayıcılar ve bu ürünü üreten ve satan işletmelerin yöneticileri olmaları sebebiyle düğün organizatörlerinin ve otel yöneticilerinin cevapları üzerinden yapılmıştır. Bu destinasyonda düğün turizminin nasıl geliştirilebileceğine ilişkin değerlendirmeler ise katılımcıların tümünün cevapları üzerinden yapılmıştır.

\section{1. İstanbul'un Düğün Turizmindeki Mevcut Durumu}

Düğün turizminin İstanbul'da nasıl geliştirilebileceğini değerlendirmek için katılımcıların düğün turizmindeki mevcut duruma ilişkin verdikleri cevaplar incelenmiştir. Katılımcılar çiftlerin ne tür düğünleri tercih ettiklerine ilişkin yöneltilen soruya, alkollü/alkolsüz yemekli düğünler, müzikli eğlencesi olan ve kapalı salonlar ya da havuz, plaj, bahçe gibi açık havadaki alanlar cevapları verilmiştir. Düğün turizmi kapsamında verilen hizmetlerin fiyatlarının nasıl belirlendiğine ilişkin soruya ise katılımcıların tamamı maliyetlere göre fiyatlandırma yaptıklarını söylemiştir. Düğün paketlerinin fiyat aralığı ile ilgili soruya ise, 20-120 avro arasında değişen kuver ücretleri olduğu ve 4 bin TL'den 250 bin TL'ye kadar değişen, hatta medyaya da yansıyan lüks Hint düğünleri olması durumunda 2-3 milyon TL'lik düğünlerin olabildiği cevabı verilmiştir.

Tablo 1: İstanbul'da Düğün Turizmi Kapsamında Verilen Hizmetler

\begin{tabular}{|c|c|c|c|c|c|}
\hline Gruplar & İfadeler & $\sum \mathbf{i}$ & $\sum i(85)$ & $\%$ & $\% 100,00$ \\
\hline \multirow[t]{3}{*}{ Ulaşım } & Transfer & 11 & \multirow[t]{3}{*}{21} & 12,94 & \multirow[t]{3}{*}{24,71} \\
\hline & Ulaşım & 5 & & 5,88 & \\
\hline & Araç Kiralama & 5 & & 5,88 & \\
\hline \multirow[t]{3}{*}{ Konaklama } & Konaklama & 17 & \multirow[t]{3}{*}{20} & 20 & \multirow[t]{3}{*}{23,53} \\
\hline & Balayı & 2 & & 2,35 & \\
\hline & Çamaşırhane Hizmetleri & 1 & & 1,17 & \\
\hline Yiyecek-l̇çecek & Banket & 17 & 17 & 20 & 20 \\
\hline \multirow{3}{*}{ Tören } & Tören Ritüelleri & 8 & \multirow[t]{3}{*}{12} & 9,41 & \multirow[t]{3}{*}{14,11} \\
\hline & Çiçek & 2 & & 2,35 & \\
\hline & Düğün Kıyafetleri & 2 & & 2,35 & \\
\hline \multirow{3}{*}{$\begin{array}{l}\text { Düğün } \\
\text { Ekstraları }\end{array}$} & Fotoğraf & 5 & \multirow[t]{3}{*}{11} & 5,88 & \multirow[t]{3}{*}{12,95} \\
\hline & Müzik & 5 & & 5,88 & \\
\hline & Gelin Hamamı & 1 & & 1,17 & \\
\hline \multirow{2}{*}{$\begin{array}{l}\text { Yasal } \\
\text { Prosedürler }\end{array}$} & Yasal İşlemler & 2 & \multirow[t]{2}{*}{4} & 2,35 & \multirow[t]{2}{*}{4,70} \\
\hline & Danışmanlık & 2 & & 2,35 & \\
\hline
\end{tabular}

İstanbul'da düğün organizatörleri ve otel yöneticileri düğün turizmi kapsamında $\% 24,71$ ile ulaşım, \%23,53 ile konaklama ve \%20 ile yiyecek içecek ve \%14,11 ile düğün töreni hizmetleri vermektedir. Düğünlerle ilgili danışmanlık hizmetlerini ise yalnızca düğün organizatörleri verdiklerini belirtmiştir. Düğün ekstralarında yer alan 
gelin hamamını ise bir otel, düğün organizasyonlarında promosyon olarak verdiklerini belirtmiştir. Yine düğün kıyafetlerinin teminini yalnızca düğün organizatörleri sağladıklarını belirtmiş; bunların düğün için hazırlanması, temizlenmesi, ütülenmesi gibi hizmetleri ise yalnızca bir otel yöneticisi söylemiştir. Gruplar bazında en çok ulaşım öne çıksa da, konaklama ve banket en sık verilen hizmetler olarak belirtilmiştir. Düğün turizminde müşterilerin özel istekleri ile ilgili İstanbul'da dini ve etnik törenler ağırlık göstermektedir. Otel yöneticilerinden biri, bu konuyla ilgili olarak otellerinde bir şapel olduğunu da ifade etmiştir. Katılımcılar, evlenecek çiftlerin düğünlerinde sıkça kendi yörelerine ait bazı yiyecek-içecekleri talep ettiklerini, bazen kendi imkânları ile karşıladıklarını bazen de çiftlerin ülkesinden istenilen yiyecek-içeceği ya da aşçı getirerek bu tür istekleri yerine getirdiklerini söylemiştir.

Son yıllarda turizmde Türkiye'yi tercih eden ülkeler arasında sıralaması yükselen Orta Doğu ülkelerinin $(\% 35,14)$ düğün turizminde İstanbul'a en çok talep eden ülkeler arasında ilk sırayı aldığı tespit edilmiştir. Bu ülkelerin vatandaşlarının İstanbul'a olan ilgilerinde, İstanbul'un tarihi geçmişinin, boğazın eşsizliğinin, tarihi yapıların ve Türk dizilerinin etkisinin olduğu katılımcıların cevaplarından çıkarılan başlıca sebeplerdir. İstanbul için düğün sektöründe iç pazarın da önemli olduğu \%27,02 ile ikinci sırada yer almasından görülmektedir. Türkiye'de en çok göç alan şehir olması, en kalabalık nüfusa sahip olması, Dünya'da en çok nikâhın kıyıldığı iki şehirden biri olması, iç pazarın önemini korumasına sebep olarak gösterilebilir. İç pazarın ardından \%21,63 ile Avrupa ülkeleri ve \%16,21 ile Hindistan gelmektedir. Avrupa ülkelerinin İstanbul'un turizm sektöründeki mevcut pazarları olması sebebiyle düğün turizminde de yer alırken, \%16,21 ile Hindistan son sırada yer almaktadır. İstanbul'da yapılan milyon dolarlık Hint düğünlerinin İstanbul'a olan ilgiyi arttırdığı katılımcıların cevapları dikkate alınarak söylenebilir.

Düğün organizatörleri ve otel yöneticileri, düğün turizminde İstanbul'un en çok tercih edildiği ayların Mayıs, Haziaran, Temmuz, Ağustos ve Eylül olduğunu belirtmiştir. Güneşli bir günde düğün yapılmasıyla ilgili isteklerin önemli olduğu ve bu durumun İstanbul'da da kendini gösterdiği söylenebilir. Düğün turizminde İstanbul'un en çok tercih edildiği günlerin Cumartesi ve Pazar olduğu belirtilmiştir. İstanbul'daki katılımcılar, çiftlerin düğüne katılacak misafirler için daha uygun olabileceğini (iş, okul, vb.) düşünerek gün tercihlerinde haftasonlarını tercih ettiklerini belirtmişlerdir. Cuma günü de ertesi günün haftasonuna denk gelmesi sebebiyle tercih edilen günlerden biri olarak belirtilmiştir.

İstanbul'daki düğün hizmetlerinin uluslararası pazarlara sunulduğu dağıtım kanallarında \%37,50 ile seyahat acentalarının, \%33,33 ile de organizasyon şirketlerinin en çok kullanılan aracılar olduğu belirtilmiştir. İstanbul'da \%29,17 ile internet üzerinden hizmet veren organizasyon şirketlerinin de yaygın olarak aracılık ettiği söylenmiştir. Katılımcılara düğün turizminde İstanbul için kullandıkları satış geliştirme stratejileri sorulduğunda, verilen cevapların başında \%42,35 ile ürünle ilgili stratejiler gelmektedir. Ürün ve fiyat çeşitlendirmesi yaparak daha fazla müşteri profiline hitap etmek, hizmet kalitesini arttırarak ve müşteri memnuniyetini göz önünde bulundurarak kulaktan kulağa reklam yapılması en yaygın strateji olarak belirtilmiştir. İkinci sırada ise, \%37,25 ile medyada yer alma gelmektedir. Bu yeni turizm ürününün mevcut ve potansiyel pazarlarda bilinirliğinin arttırıması satışların arttırılmasında katılımcılar tarafından önemli görülmüştür. Son sırada ise, $\% 20$ ile aracılar ve potansiyel müşteri ve aracılarla ilişki kurmak için fuarlara katılım yer almaktadır. Potansiyel aracılarla ilişki kurmak diğer turizm ürünlerinde olduğu gibi satılan ürünlerin daha geniş kitlelere ulaşmasında etkili görülmüştür. 


\section{2. İstanbul'da Düğün Turizminin Geliştirilmesi}

Katılımcıların tamamının görüşleri doğrultusunda çalışmanın bu kısmında İstanbul'da düğün turizminin geliştirilebilmesi için neler yapılabileceğine ilişkin katılımcıların kolektif görüşleri değerlendirilmiştir. Gerek katılımcı sayısının az olması gerekse bütünsel bir yaklaşım benimsenmek istendiği için katılımcılar arasında bir karşılaştırma yapılmamıştır.

İstanbul'da düğün turizmi geliştirilmeli mi, İstanbul'un tanıtımında düğün turizmi yer almalı sorusuna katılımcıların $\% 91$ 'i İstanbul'da düğün turizmi geliştirilmeli ve İstanbul'un tanıtımında düğün turizmi yer almalı cevabını verirken, \%9'u bu sorulara olumsuz yanıt vermiştir. Olumlu yanıt verenler, İstanbul'un düğün turizminde potansiyelinin olduğunu ve bu ürünün turizm gelirlerini arttırabileceğini belirtmiştir. Olumsuz yanıt verenler ise, İstanbul'da düğün sektörünün yeterli büyüklükte olduğunu ve zaten kendiliğinden büyüdüğüne değinmiştir. Bu sebeple her hangi bir çabanın harcanmasına gerek olmadığı görüşünü savunmuşturlar.

Yabancıların İstanbul'da düğün yapabilecekleri ideal yerlerin, katılımcıların $\% 48,31$ 'i sahip oldukları olanaklar ile turistik tesisler olduğunu belirtmiştir. İstanbul'da düğün yapılabilecek diğer ideal yerler ise, \%31,46 ile doğal, kültürel yerler (tarihi yarımada, boğaz manzaralı, deniz manzaralı vb.) ve \%20,22 ile tarihi mekânlar (saraylar, yalılar, kasırlar vb.) olarak tespit edilmiştir. Daha genel bir değerlendirme ile katılımcılar tarafından İstanbul'da yabancıların dügün yapabilecekleri ideal yerler olarak; lüks turistik tesisleri ve İstanbul'un doğal güzelliği ve eşsiz yönü olarak tarif edilen boğaz ile bu manzaraya eşlik eden tarihi yerleri ve mekânları, imparatorluk geçmişinden kalan yapıları düğün için uygun yerler olarak öne sürülmüştür.

İstanbul'un düğün turizminde hedef pazarlarının nereler olması gerektiği ile ilgili katılımcılar, Türkiye turizminde son yıllarda gelişen pazarlar olan Orta Doğu ülkelerini \%36,56 ile düğün turizminde ilk sırada yer alması gereken pazarlar olarak belirtmiştir. Türk dizilerinin etkisi, İstanbul'un imparatorluk geçmişi, kültürel mirası ve boğazın çekiciliği ile Orta Doğulu turistlerin artan Türkiye ilgileri, kişi başı harcama miktarları ve lüks düğün zevkleri sebebiyle Orta Doğu ülkelerinin ilk sırada yer almasını sağlamıştır. Avrupa ülkeleri, \%24,74 ile ikinci sırada yer almaktadır. Katılımcılar, Türkiye'nin uzun yıllardır en büyük turizm pazarı olan Avrupa ülkelerinin düğün turizminde de potansiyel hedef pazarlar olması gerektiği görüşünü paylaşmıştır. Bu pazarlarda İstanbul'un bilinir olması, coğrafi yakınlık ve direkt uçuş sayıları, turizm profesyonellerinin bu pazarlar hakkında bilgi birikiminin olması, bu yeni ürünün pazarlanmasında avantaj olarak gösterilmiştir. Üçüncü sırada ise, \%19,34 ile Uzak Doğu ülkeleri potansiyel düğün turizm pazarları olarak belirtilmiştir. İç pazar ve üst gelir grubunda olan kişiler de \%9,68 ile önemli hedef pazarlar olarak belirtilmiştir.

İstanbul'un düğün turizmindeki rakipleri olarak ilk sırada \%62,26 ile Avrupa ülkeleri (İspanya, İtalya, Yunanistan, Fransa, İspanya, Balkan ülkeleri) ve şehirleri (Paris, Roma, Barselona, Milano, Londra, Venedik, Como, Saint-Tropez) gösterilmiştir. Paris ve Roma ilk sırada gösterilen Avrupa şehirleridir. İmparatorluk geçmişleri ile tarihi, kültürel birikimleri ve somut mirasları ile İstanbul ile benzer görülmüş ve rakip olarak belirlenmiştir. Ayrıca coğrafi yakınlıkları ile de bu şehirler İstanbul için düğün turizminde rakip olarak görülmüştür. İkinci sırada \%27,35 ile Türkiye'deki turizm şehirleri (İzmir, Antalya, Muğla (Fethiye, Ölüdeniz), Nevşehir (Kapadokya)) yer almıştır. Türk turizminde önemli payı olan bu şehirler, turizmdeki bilinirlikleri, turistik çekicilikleri, tesisleri, hazır altyapı ve üstyapısıyla İstanbul'a rakip olarak görülmüştür. İzmir, İstanbul'un ilk sıradaki rakibi olmuştur. Yine Antalya, Muğla ve Nevşehir de düğün 
turizminin geliştirilen diğer Türk şehirleridir. İstanbul'un rakibi olarak üçüncü sırada gösterilen yerler ise, \%8,53 ile ABD şehirleridir (Las Vegas, Los Angeles, New York, Havai). Özellikle dünyada en çok evliliğin yapıldığı 2 şehirden biri olan Las Vegas (diğeri İstanbul) bu grup içinde İstanbul'un ilk sıradaki rakibi olarak görülmüştür. Bu şehir aynı zamanda; hızlı nikâh prosedürleri, düğün şapelleri (resmi evrakların düzenlenmesi 10 dakika, nikâh töreni 15 dakika) ile bilinen ve düğün yapanların \%90'ının Nevada eyaleti dışından gelenlerin oluşturması ile şüphesiz dünyanın en büyük düğün turizm destinasyonudur (Drrsvcs, 2016). Katılımcılar nikâh sayısında olduğu gibi düğün turizminde de bu şehri rakip olarak görmüştür. Son sırada ise, $\% 1,86$ ile bölgedeki Arap şehirleri (Beyrut ve Dubai) belirtilmiştir.

Çalışma kapsamında, İstanbul'un düğün turizmi ürünün pazarlanmasında, düğün turizminde bilinir bir destinasyon olmasında güçlü ve zayıf yönleri ile bu destinasyonda düğün turizminin geliştirilmesi ve dünya düğün turizm pazarından daha fazla pay alabilmesi için önündeki fırsatların ve tehditlerin neler olduğu belirlenmek üzere sorular sorulmuştur. Alınan cevaplara içerik analizi uygulanmıştır.

Tablo 2: İstanbul’un Düğün Turizmindeki Güçlü Yönleri

\begin{tabular}{|c|c|c|c|c|c|}
\hline Gruplar & İfadeler & $\sum \mathbf{i}$ & $\sum i(213)$ & $\%$ & $\% 100,00$ \\
\hline Altyapı ve & Ulaşım Kolaylığı & 21 & 101 & 9,86 & 47,43 \\
\hline \multirow[t]{8}{*}{ Üstyapı } & Alternatif Yerlerin Olması & 19 & & 8,92 & \\
\hline & Hizmet Kalitesi & 10 & & 4,69 & \\
\hline & Lüks Oteller & 10 & & 4,69 & \\
\hline & Boğaz Kenarındaki Tesisler & 10 & & 4,69 & \\
\hline & Uzmanlaşmış Organizatörlerin Olması & 7 & & 3,29 & \\
\hline & Rekreasyon Alanları & 6 & & 2,82 & \\
\hline & Kır Düğünü Mekânları & 5 & & 2,34 & \\
\hline & Direkt Uçuşlar & 4 & & 1,88 & \\
\hline \multirow[t]{7}{*}{ Çekicilikler } & İstanbul Boğazı & 23 & 80 & 10,80 & 37,56 \\
\hline & Doğal Güzellikler & 15 & & 7,05 & \\
\hline & Tarihi Doku & 10 & & 4,69 & \\
\hline & Manzara & 10 & & 4,69 & \\
\hline & Deniz & 9 & & 4,23 & \\
\hline & Tarihi Geçmişi & 8 & & 3,76 & \\
\hline & Saraylar & 5 & & 2,34 & \\
\hline \multirow[t]{3}{*}{ Bilinirlik } & Bilinirlik & 18 & 30 & 8,45 & 14,08 \\
\hline & Marka Şehir Olması & 9 & & 4,23 & \\
\hline & Popüler Olması & 3 & & 1,40 & \\
\hline \multirow[t]{2}{*}{ Fiyatlar } & Döviz Kuru & 9 & 11 & 4,23 & 11,74 \\
\hline & Fiyat Çeşitliliği & 2 & & 0,93 & \\
\hline
\end{tabular}

Tablo 2' de sunulduğu gibi katılımcıların görüşleri doğrultusunda İstanbul'un düğün turizmindeki güçlü yönleri $\% 47,43$ ile ilk sırada mevcut altyapı ve üstyapı imkânları olarak belirlenmiştir. İstanbul'un direkt uçuşlarla ve konumuyla sağladığı ulaşım kolaylığı, düğün sektöründeki tecrübeli organizatörleri, lüks otelleri, tarihi mekânları, rekreasyon alanları ve boğaz manzaralı tesisleri ile düğün yapılabilecek yerlerin fazlalığı İstanbul'un ilk sıradaki diğer güçlü yönleridir. İkinci sırada ise, \%37,56 ile İstanbul'un sahip olduğu doğal, kültürel çekicilikler yer almaktadır. Bu grupta İstanbul Boğazı destinasyonun en güçlü yönü olarak belirtilmiştir. Çiftlerin farklı, eşsiz bir düğün yapma isteği İstanbul'un çekiciliklerini güçlü kılmaktadır. Üçüncü sırada $\% 14,08$ ile İstanbul'un dünyadaki bilinirliği ve marka değeri gelirken, \%11,74 ile Türkiye'de döviz kurlarının yüksek olması sebebiyle çiftlerin kendi ülkelerine göre düğünlerin daha uygun fiyata gelmesi ve fiyat çeşitliliği bulunmaktadır. 
Tablo 3: İstanbul’un Düğün Turizmindeki Zayıf Yönleri

\begin{tabular}{|c|c|c|c|c|c|}
\hline Gruplar & Iffadeler & $\sum \mathbf{i}$ & $\sum i(90)$ & $\%$ & $\% 100,00$ \\
\hline \multirow[t]{3}{*}{ Şehir Planlaması Sorunları } & Nüfus Yoğunluğu & 11 & \multirow[t]{3}{*}{28} & 12,23 & \multirow[t]{3}{*}{31,11} \\
\hline & Trafik & 9 & & 10 & \\
\hline & Betonlaşma & 8 & & 8,88 & \\
\hline \multirow[t]{2}{*}{ Tanıtım Sorunları } & Yeterli Tanıtım Yapılmaması & 19 & \multirow[t]{2}{*}{22} & 21,12 & \multirow[t]{2}{*}{24,45} \\
\hline & Yeterli Reklam Yapılmaması & 3 & & 3,34 & \\
\hline \multirow{3}{*}{$\begin{array}{l}\text { Rekabet } \\
\text { Gücü }\end{array}$} & Fiyatların Yüksek Olması & 8 & \multirow[t]{3}{*}{21} & 8,88 & \multirow[t]{3}{*}{23,34} \\
\hline & Rekabet & 7 & & 7,78 & \\
\hline & Vergiler & 6 & & 6,68 & \\
\hline \multirow{2}{*}{$\begin{array}{l}\text { Siyasi } \\
\text { Problemler }\end{array}$} & Güvenlik & 11 & \multirow[t]{2}{*}{19} & 12,22 & \multirow[t]{2}{*}{20} \\
\hline & Siyasi Krizler & 8 & & 8,88 & \\
\hline
\end{tabular}

Bir mega kent olmasından kaynaklanan nüfus yoğunluğu ve ulaşım altyapısındaki eksikler, yaşanan trafik sorunu, çarpık kentleşme ve betonlaşma gibi sorunlar \%31,11 ile şehir planlaması sorunları olarak İstanbul'un düğün turizmindeki zayıf yönlerinin başında yer aldığı tablo 3'te görülmektedir. İnsanların şehir içinde bir yerden bir yere gitmesinin çok zaman alması ve çok kalabalık bir şehir olması düğün organizasyonlarında sorun yaratabileceği; bu durumun İstanbul'da düğün turizminin gelişimi için zayıfığa neden olduğu belirtilmiştir. İkinci sırada ise, \%24,45 ile tanıtım sorunları gelmektedir. Hem İstanbul için turizm sektöründe yeterince tanıtım yapılmadığı hem de düğün turizminde yeterince tanınmadığı savunulmuştur. Üçüncü sırada ise, \%23,34 ile sektör temsilcilerinin yüksek vergiler ve ürün fiyatları sebebiyle maliyetlerinin artmasının rekabet güçlerini düşürmesi yer almaktadır. Son sırada ise \%20 ile siyasi problemler yer almaktadır. Komşu ülkelerdeki savaş durumu, artan terör olayları ve diğer güvenlik sıkıntıları ile ülkenin uluslararası politikalarındaki dalgalanmaların turizm sektörünü, dolayısıyla düğün turizmini olumsuz etkilediği belirtilmiştir.

Tablo 4: İstanbul İçin Düğün Turizmindeki Fırsatlar

\begin{tabular}{|c|c|c|c|c|c|}
\hline Gruplar & İfadeler & $\sum \mathbf{i}$ & $\sum i(84)$ & $\%$ & $\% 100,00$ \\
\hline \multirow{6}{*}{$\begin{array}{l}\text { Pazarlardaki } \\
\text { Yönelimler }\end{array}$} & Bilinirlik & 17 & \multirow[t]{6}{*}{65} & 20,24 & \multirow[t]{6}{*}{77,38} \\
\hline & Türk Dizileri & 16 & & 19,05 & \\
\hline & Merak Uyandırması & 3 & & 3,57 & \\
\hline & Arap Pazarının İlgisi & 13 & & 15,48 & \\
\hline & Komşuların Tercihi & 11 & & 13,09 & \\
\hline & Gelişen Uzakdoğu Pazarı & 5 & & 5,95 & \\
\hline \multirow[t]{2}{*}{ Erişilebilirlik } & Ulaşım Kolaylığı & 16 & \multirow[t]{2}{*}{19} & 19,05 & \multirow[t]{2}{*}{22,62} \\
\hline & Vizesiz Seyahat & 3 & & 3,57 & \\
\hline
\end{tabular}

Tablo 4' te sunulduğu gibi İstanbul'un dünyada bilinen bir şehir olması, Türk dizileriyle yapılan dolaylı tanıtımlar, komşuların yakın ve bilinen bir destinasyonu tercih etmeleri, Arap ülkelerinde Türk dizileriyle oluşan merak ve Uzak Doğu ülkelerinde yurt dışında düğün yapma yönelimleri $\% 77,38$ ile ilk sırada yer alan fırsatlar olarak değerlendirilmiştir. İkinci ve son sırada ise, \%22,62 ile direk uçuşlar ve coğrafi konumdan ve mevcut dügün turizm pazarlarına yakınlıktan kaynaklı ulaşım kolaylığı, birçok ülkeyle yapılan vizesiz seyahat anlaşmalarının sağladığı erişilebilirlik fırsatları bulunmaktadır. 
Tablo 5: İstanbul İçin Düğün Turizmindeki Tehditler

\begin{tabular}{|c|c|c|c|c|c|}
\hline Gruplar & Ífadeler & $\sum \mathbf{i}$ & $\sum i(69)$ & $\%$ & $\% 100,00$ \\
\hline \multirow[t]{4}{*}{ Siyasi Problemler } & Siyasi Sorunlar & 13 & \multirow[t]{4}{*}{37} & 18,84 & \multirow[t]{4}{*}{53,62} \\
\hline & Güvenlik & 10 & & 14,49 & \\
\hline & Terör Olayları & 10 & & 14,49 & \\
\hline & Mülteciler & 4 & & 5,80 & \\
\hline \multirow{3}{*}{$\begin{array}{l}\text { Sektörel } \\
\text { Problemler }\end{array}$} & Tanıtım Eksikliği & 10 & \multirow[t]{3}{*}{19} & 14,49 & \multirow[t]{3}{*}{27,53} \\
\hline & Yüksek Gelir Grubuna Hitap Etmesi & 5 & & 7,24 & \\
\hline & Rekabet & 4 & & 5,80 & \\
\hline \multirow[t]{2}{*}{ Nüfus Yoğunluğu } & Kalabalık & 9 & \multirow[t]{2}{*}{13} & 13,04 & \multirow[t]{2}{*}{18,84} \\
\hline & Trafik & 4 & & 5,80 & \\
\hline
\end{tabular}

İstanbul için, ilk sırada \%53,62 ile siyasi problemler düğün turizminin gelişimi için önemli tehdit olarak görüldüğü tablo 5' te sunulmuştur. Suriye'deki iç savaş, bölgedeki uluslararası terör olayları, yurtiçindeki terör faaliyetleri, komşu ülkelerdeki siyasi problemler sebebiyle yaşanan göç ve ülkenin uluslararası siyasetindeki gerginlikler İstanbul'da düğün turizminin gelişimini olumsuz etkileyebilecek en büyük tehdit olarak belirlenmiştir. İstanbul'un turizm sektöründe düzgün tanıtılmamasıyla ilgili sorunlar, düğün turizminde yalnızca lüks düğünlerle kendini duyurması, Avrupa başkentleri ve turistik şehirleri ile rekabet etmek zorunda olması ve Avrupa Birliği ülkeleri arasındaki vizesiz seyahat serbestliği \%27,53 ile sektörel problemler olarak ikinci sırada yer alan tehditler olarak tespit edilmiştir. İstanbul için düğün turizmindeki tehditler arasında \%18,84 ile İstanbul'un nüfusunun her geçen gün artması ve nüfus yoğunluğu ve altyapı eksikliğinden kaynaklanan trafik sorunlarının kısa vadede çözülemeyecek boyutta olması yer almaktadır. Trafik sorunları sebebiyle çiftlerin geç kalmak, trafikte vakit kaybetmek istememeleri gibi düğünleri olumsuz etkileyebilecek nedenlerle düğün turizminde İstanbul'u tercih etmek istememe ihtimalleri, nüfus yoğunluğunun düğün turizminde bir tehdit olarak görülmesine neden olmuştur.

İstanbul'un düğün turizminde marka bir destinasyon olabilmesi için yapılması gerekenler sorulmuş ve alınan cevaplarda \% 55,04 ile çekiciliklere ilişkin öneriler ilk sırada yer almıştır. İstanbul Boğazı'nın, doğal güzelliklerin, soyut ve somut mirasının kullanılarak, tarihi geçmişi ve etnik temalar kullanılarak İstanbul'un marka bir destinasyon olması sağlanabilir görüşü belirtilmiştir. İkinci sırada ise, \%25,58 ile doğru bir şekilde yapılmış planlama, profesyonel tanıtım ve reklam faaliyetleri ile İstanbul'un kolay ulaşılabilir bir destinasyon olduğunun vurgulanması gerektiği savunulmuştur. Son olarak ise, İstanbul'daki turizm tesislerinin varlığı, bu tesislerin sunduğu hizmetin kalitesinin arttırılması, farklı pazarlara hitap edebilecek fiyat çeşitliliğinin sağlanması ve en ikna edici reklam aracı olan müşterilerin destinasyonu olumlu olarak anlatması için düğün organizasyonlarında müşteri memnuniyetinin dikkate alınması, \%19,38 ile bu destinasyonun marka bir şehir olması için yapılabilecek önemli şeyler olarak bulunmuştur.

İstanbul 'un düğün turizmindeki pazar payının büyütülmesi için yapılması gerekenler hakkında katılımcıların görüşlerinin arasında ilk sırada \%52,89 ile pazarlama faaliyetleri yer almaktadır. İstanbul'un düğün turizmi ile tanıtılması, destinasyonun sağladığı düğün olanaklarının reklamının yapılması, düğün fuarlarına katıım, düğün turizmindeki pazar payının büyütülmesi için gerekli görülmüştür. Ayrıca 
internet odaklı bir pazarlama çalışması ile destinasyonun düğün turizmi ürünleri hakkında ünlü blog yazarlarına yazılar yazdırılması, sosyal medyanın aktif kullanılması gibi faaliyetlerle internette yer almanın pazar payını arttıracağı savunulmuştur. İkinci sırada \%25,61 ile ürüne ilişkin öneriler yer almaktadır. Düğün turizmi ürünlerinin ve fiyat seçeneklerinin çeşitlendirilmesi, kaliteli hizmet sunularak müşterilerin memnuniyetinin sağlanması gerektiği görüşleri sunulmuştur. Üçüncü olarak, \%14,04 ile ülkedeki siyasi sıkıntıların ve politik gerilimlerin azaltılmasının da, İstanbul'un düğün turizmindeki pazar payının büyütülmesine katkı sağlayacağı belirtilmiş ve özellikle terör olaylarından kaynaklı güvenlik sorunlarının çözülmesi gerektiğine değinilmiştir. Son olarak, \%7,43 ile İstanbul'un düğün turizmindeki pazar payının büyütülmesi için paydaşların işbirliği yapmasının önemi ve destinasyon yönetiminin bir çatı altında toplanmasının önemli olduğu belirtilmiştir.

\section{Tablo 6: Düğün Turizminin Hedef Pazarlara Sunulmasında Kullanılabilecek Sloganlar}

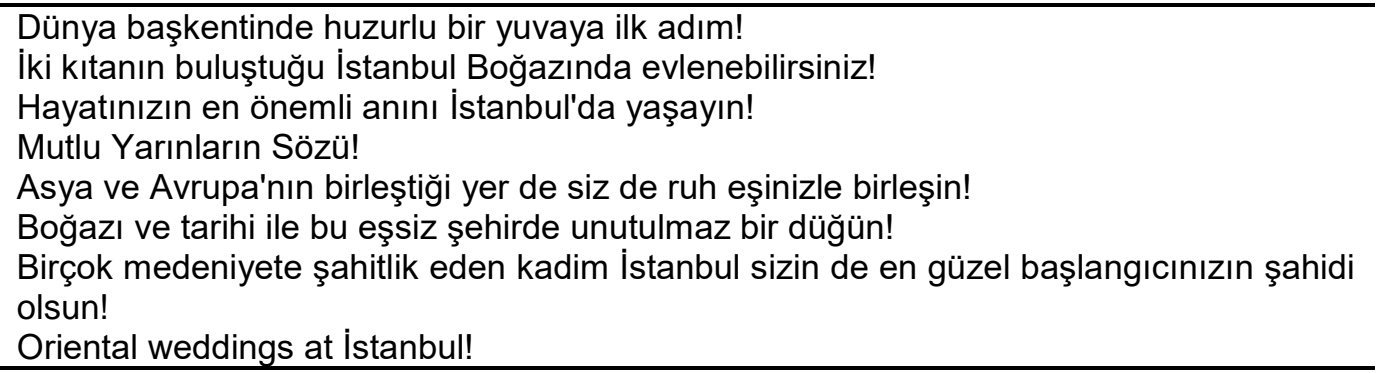

Katılımcıların İstanbul'un düğün turizminin hedef pazarlara nasıl bir sloganla sunulması gerektiğine dair fikirleri Tablo 6' da sunulmuştur. İstanbul'un Boğazını, tarihi geçmişini, kültürel birikimini, coğrafi ve siyasi konumunu vurgulayan ifadeler önerilmiştir.

Düğün turizmiyle ilgili katılımcılara sorulan son soru ise, Türkiye'nin düğün turizmindeki pazar payının büyütülmesi için neler yapılması gerektiğidir. İlk sırada $\% 48,48$ ile pazarlama faaliyetlerine ilişkin öneriler yer almıştır. Türkiye'nin düğün turizmi olanaklarının tanıtılması, turizm destinasyonlarındaki düğün turizmi ürünlerinin reklamının yapılması, düğün fuarlarına katıım, düğün turizmindeki pazar payının büyütülmesi için gerekli görülmüştür. Ayrıca düğün turizmi ile ilgili TV programları yapılması, promosyonlar geliştirilerek çiftlerin düğün turizminde Türkiye'deki destinasyonları tercih etmelerinin teşvik edilmesi öneriler arasında yer almaktadır. İkinci sırada \%32,38 ile ürüne ilişkin öneriler yer almaktadır. Düğün turizmi ürünlerinin ve fiyat seçeneklerinin çeşitlendirilmesi, profesyonel turizm çalışanları ile kaliteli hizmet sunularak müşterilerin memnuniyetinin sağlanması gerektiği görüşleri sunulmuştur. Üçüncü olarak, \%10,52 ile ülkedeki siyasi sıkıntıların ve politik gerilimlerin azaltılmasının Türkiye'nin düğün turizmindeki pazar payının büyütülmesine katkı sağlayacağı belirtilmiş ve özellikle terör olaylarından kaynaklı güvenlik sorunlarının çözülmesi gerektiğine değinilmiştir. Ekonomik istikrarın sağlanması da düğün turizmine yatırım yapılabilmesi ve yatırımcıların rekabet gücünü koruyabilmeleri açısından önemli görülmüştür. Katılımcılar, \%6,88 ile Türkiye'nin düğün turizmindeki pazar payının büyütülmesi için paydaşların işbirliği yapmasının ve destinasyon yönetiminin bir çatı altında sağlanmasının önemli olduğu belirtilmiştir. Son olarak ise, \%1,61 ile Türkiye'nin düğün turizmindeki pazar payının büyütülmesine gerek olmadığı, zaten yeterli büyüklükte olduğu ve kendiliğinden büyüdüğünü savunanlar olmuştur. 


\section{Sonuç ve Öneriler}

İstanbul, bir dünya kenti olarak neredeyse her etnik ve dini yapıyı kendi içinde barındıran ve bu özelliği ile de düğün turizminde birçok etnik ve kültürel talebe cevap verebilecek olanaklara sahiptir. Bu farklı gelişmeler, bir anlamda kendiliğinden bir pazar bölümlendirmesi oluştuğu şeklinde de yorumlanabilir. Ancak yine de tanıtım çalışmalarında araştırma bulgularından yararlanmak faydalı olacaktır. Çalışmaya katılanlar, evlenecek çiftlerin düğünlerinde sıkça kendi yörelerine ait bazı yiyecekiçecekleri talep ettiklerini, bazen kendi imkânları ile karşıladıklarını, bazen de çiftlerin ülkesinden istenilen yiyecek-içeceği ya da aşçı getirerek bu tür istekleri yerine getirdiklerini belirtmişlerdir. Bir dünya kenti olan İstanbul, birçok etnik köken ve kültürün yaşaması nedeniyle çok sayıda farklı ülkeye ait restoranlara sahiptir. Bu özelliği nedeniyle talep edilen farklı yiyecek içeceklerin önemli kısmı İstanbul içinden karşılanabilir. Düğün turizmi yiyecek-içecek sektörünün de büyümesine imkân sağlayabilir. İstanbul, tarihsel, kültürel ve coğrafi özelliklerini kullanarak Ortadoğu başta olmak üzere tüm dünyaya ve özelikle de üst gelir grubuna, İstanbul boğazı, boğaziçi ve gerekirse boğaz köprüleri de kullanılarak romantizm ve farklıık arayışında olan çiftlere pazarlanabilir. İyi bir planlama ve tanıtım yapılırsa İstanbul, Las Vegas gibi dış kaynaklı düğün rakamlarına ulaştırılabilir. Düğün turizmi gibi yeni bir ürünle turizm sektöründe yeni bir gelir kaynağı yaratılabilir. Misafirlerin düğün dışındaki harcamaları ve destinasyonu gezme istekleri iyi bir şekilde değerlendirilebilirse turizm gelirlerinin arttırımasına olumlu yansıyabilir.

Düğün turizminin çiftlerin ve davetlilerin destinasyon ile uzun süreli ilişki yaratmaya katkı sağladığı, bu ziyaretçilerin destinasyona tekrar gelme olasılıklarının yanı sıra evlenen çiftlerin çocuk sahibi olmaları durumunda; çocuklarının da ebeveynlerinin evlendikleri destinasyona turist olarak gelme intimallerinin olduğu göz önünde bulundurulmalıdır. Turistik alanlarda ve özellikle tarihi yarımadada uygulanabilecek ulaşım çözümleri ile turistlerin İstanbul'un nüfus yoğunluğundan ve trafiğinden en az ölçüde etkilenmesi sağlanabilir. İstanbul'un düğün turizminde en çok öne çıkan çekiciliği olan boğaz ve çevresindeki tesisler ile tarihi yapılar bu ürün kapsamında değerlendirilir, bu bölgede çiftler ve misafirleri için alternatif ulaşım imkânları sunulabilirse, olumsuzluklar giderilebilir hatta düğün turizminde yeni bir çekicilik unsuru yaratılabilir. Türkiye'nin bölge barışına katkı sağlayacak politikalar izlemesi ve komşularla iyi ilişkiler kurması, uluslararası siyasette olumlu politikalar geliştirmesi İstanbul için düğün turizminde önemli bir büyüme sağlayabilir. Son zamanlarda bu konularda yaşanan gelişmelerin turizm sektörü üzerinde, dolayısıyla düğün turizminde olumsuz etkileri olduğu belirtilmiş ve bu konularda önlemler alınması gerektiği vurgulanmıştır.

Düğün turizmi ile ilgili yazındaki ve bu çalışmadaki bulgular ışığında turizmin tüm yıla yayılması için bu ürünün gelişiminin desteklenmesi gerektiği düşünülmektedir. Başta İstanbul olmak üzere Türkiye'nin düğün turizmindeki pazar payının büyütülmesi için yapılması gerekenler, Türkiye'nin düğün turizmi olanaklarının tanıtılması, turizm destinasyonlarındaki düğün turizmi ürünlerinin reklamının yapılması, düğün fuarlarına katıım, düğün turizmi ile ilgili TV programları yapılması, promosyonlar geliştirilerek çiftlerin düğün turizminde Türkiye'deki destinasyonları tercih etmelerinin teşvik edilmesi düğün turizmi ürünlerinin ve fiyat seçeneklerinin çeşitlendirilmesi, profesyonel turizm çalışanları ile kaliteli hizmet sunularak müşterilerin memnuniyetinin, ülkedeki siyasi sıkıntıların ve politik gerilimlerin azaltılması, terör olaylarından kaynaklı güvenlik sorunlarının çözülmesi, paydaşların işbirliği yapması olarak belirlenmiştir. Ekonomik istikrarın sağlanması da düğün turizmine yatırım yapılabilmesi ve yatırımcıların rekabet gücünü koruyabilmeleri açısından önemli görülmüştür. Ekonomik ve siyasi istikrar 
yalnızca düğün turizmi yatırımları için değil tüm turizm hatta tüm yatırımlar için olmazsa olmaz koşulların başında gelmektedir. Bu nedenle ülkede herkesin mal ve can güvenliği, özgürce yaşama hakkı, hukukun üstünlüğü ilkesi ve demokrasinin daha çok derinleştirilmesi yoluyla geliştirilmelidir. Bu yöndeki her uygulama ve çaba ülkenin imajının iyileşmesine katkıda bulunacaktır. İmajın iyileşmesi Türkiye'ye yönelik düğün turizmi de dâhil toplam turizm talebin artmasına katkıda bulunabilir.

Yazınla ilgili olarak, yapılan taramalarda konuyla ilgili yapılan çalışmaların çok sınırlı sayıda olduğu ve son 10 yılı kapsadığı görülmüştür. Yazında yapılan çalışmaların genellikle tanımlayıcı çalışmalar olduğu veya ikincil verilere dayandığı görülmüştür. Çalışmada, keşfedici araştırma yaklaşımının benimsenmesi ve Türkiye'de düğün turizmini inceleyen ilk çalışmalardan biri olması sebebiyle yazına önemli bir katkı sağlayacağı düşünülmektedir. Yine de çalışmanın sınırlılıkları göz önünde bulundurularak, sadece İstanbul'da düğün turizmini incelemesi ve konuyla ilgili arz odaklı bir bakış açısı sunması sebebiyle konunun yalnızca bir yönüne ışık tutabilmektedir. İstanbul'da düğün turizminin arz odaklı olarak değerlendirilmesi önemli bulunsa da, düğün turizmin katılımcıları ya da düğün turisti olarak adlandırabileceğimiz ziyaretçilerin destinasyondan ve ilgili işletmelerden taleplerinin neler olabileceğinin tespit edilmesi gerektiği İstanbul'un bu pazardaki payını arttırabilmesi için önemli görülmektedir. Bu sebeple, gelecekte tüketici odaklı olarak İstanbul'a gelen düğün turistleri üzerinde yapılacak araştırmalar, sektörün gelişimi açısından önem arz etmektedir. Son olarak, Türkiye'de İzmir, Nevşehir gibi düğün turizmi potansiyeli olan diğer şehirlerde de düğün turizmine ilişkin araştırmaların yapılması, ülkede turizm sektörünün gelişimine, ürün çeşitliliğinin arttırılmasına ve turizm sektörünün diğer destinasyonlarda da büyümesine katkı sağlayacaktır.

\section{Kaynakça}

Altunışık, R., Coşkun, R., Bayraktaroğlu, S., ve Yıldırım, E. (2012). Sosyal Bilimlerde Araştırma Yöntemleri: SPSS Uygulamalı. Sakarya: Sakarya Yayıncılık.

Arcodia, C., ve Robb, A. (2000). "A Future For Event Management: Ataxonomy Of Event Management Terms" İçinde J. Allen, R. Harris, L. Jago ve A. J. Veal (Editörler), Events Beyond 2000: Setting the Agenda, Proceedings of Conference on Event Evaluation, Research and Education ss. 154-160, Sydney: Australian Centre for Event Management.

Bertella, G. (2015). "Celebrating The Family Abroad: The Wedding Tourism Experience", Annals of Leisure Research, 18 (3), ss. 397-413.

Büyüköztürk, Ş., Çakmak, E. K., Akgün, Ö. E., Karadeniz, Ş. ve Demirel, F. (2012). Bilimsel Araştırma Yöntemleri. Ankara: Pegem Akademi Yayıncılık.

CNN Türk, (2010). "Turizmde Yeni. Trend Evlilik Turizmi" http://www.cnnturk.com/2010/ekonomi/genel/01/29/turizmde.yeni.trend.evlilik.turi zmi/ 561479.0/ (01.01.2018).

Crompton, J. L., ve McKay, S. L. (1997). "Motives Of Visitors Attending Festival Events", Annals of Tourism Research, 24 (2), ss. 425-439.

Daniels, M. ve Loveless, C. (2013). Wedding Planning And Management: Consultancy For Diverse Clients. Londra: Routledge.

De Witt, L. (2006). Key Success Factors For Managing Special Events: The Case Of Wedding Tourism. Yayımlanmamış Doktora Tezi, North-West University, Vanderbijlpark.

Del Chiappa, G. ve Fortezza, F. (2016). Tourist Behaviour. International Perspectives. Oxon: CABI. 
Demir, M., ve Demir, Ş. Ş. (2004). "Turistik Ürün Çeşitlendirmesi Kapsamında Futbol Turizmi: Antalya Bölgesinde Bir Araştırma”, Dokuz Eylül Üniversitesi Sosyal Bilimler Enstitüsü Dergisi, 6 (1), ss. 94-116.

Deng, C. (2013). "Key Factors Of Wedding Tourism In Bangkok", International Conference on Hospitality \& Tourism Management, Kolombo, 1, ss. 478-489.

Derrett, R. (2004). "Festivals, Events And The Destination" İçinde, , I. Yeoman, M. Robertson, J. Ali-Knight, S. Drummond ve U. McMahon-Beattie (Editörler), Festival and Events Management, ss. 32-64, Oxon: Routledge.

Drrsvcs, (2016). "Nevada Marriage Records" http://drrsvcs.com/nevada-marriagerecords/ (01.01. 2018).

Durinec, N. (2013). "Destination Weddings In The Mediterranean", International Conference on Hospitality and Tourism Management, Kolombo, 1, ss. 1-17.

Düğün, (2015). "Düğün Sektörünün Pastadaki Payı Büyüyor" https://dugun.com/isortagim/ pazarlama-fikirleri/dugun-sektorunun-pastadakipayi-buyuyor/18 (01.01.2018)

Dünya, (2015). “Türkiye' de Evlilik Sektörü 30 Milyar TL' yi Geçti” https://www.dunya. com/gundem/turkiyede-evlilik-sektoru-30-milyar-tlyi-gecti-haberi-282497

(01.01.2018).

Getz, D. (1990). Festivals, Special Events, and Tourism. New York: Van Nostrand Reinhold.

Getz, D. (1997). Event Management \& Event Tourism. New York: Cognizant Communication Corp.

Getz, D. (2008). "Event Tourism: Definition, Evolution, And Research", Tourism Management, 29 (3), ss. 403-428.

Haber3, (2011). "Wedding City Antalya Şirketi Genel Müdürü Özdemir Türkiye Evlilik Turizmi Yapılacak" http://www.haber3.com/wedding-city-antalya-sirketi-genelmuduru-ozdemir-turkiye-evlilik-turizmi-yapilacak--779530h.htm (01.01.2018).

Hürriyet, (2012). "Diziler Düğün Turizmini Canlandırdı Yabancılar Evlilik İçin Türkiye' yi Seçti" http://www.hurriyet.com.tr/diziler-dugun-turizmini-canlandirdi-yabancilarevlilik-icin-turkiye-yi-secti-20634796 (01.01.2018).

İpar, M. S. (2011). Turizmde Destinasyon Markalaşması ve İstanbul Üzerine Bir Uygulama. Yayınlanmamış Yüksek Lisans Tezi, Balıkesir Üniversitesi, Sosyal Bilimler Enstitüsü. Balıkesir.

Jago, L. K., Chalip, L., Brown, G., Mules, T. ve Ali, S. (2002). "The Role Of Events İn Helping To Brand A Destination", In International Event Research Conference: Events and Place Making, Proceedings, Australian Centre for Event Management, Sydney, ss. 111-143.

Kanca, B. (2018), Düğün Turizmi Kapsamında Antalya ve İstanbul Destinasyonlarının Değerlendirilmesi, Yayınlanmamış Doktora Tezi, Mersin Üniversitesi, Sosyal Bilimler Enstitüsü, Mersin.

Karagöz, D. (2006). Etkinlik Turizmi ve Etkinlik Turizmi Bağlamında Yabancı Ziyaretçi Harcamalarının Ekonomiye Etkisi: Formula 12005 Türkiye Grand Prix Örneği. Yayımlanmamış Yüksek Lisans Tezi, Anadolu Üniversitesi, Sosyal Bilimler Enstitüsü, Eskişehir.

Kim, S. S. ve Agrusa, J. (2005). "The Positioning Of Overseas Honeymoon Destinations", Annals of Tourism Research, 32 (4), ss. 887-904.

Kim, Y. ve Kim, D. (2013). "An Investigation of Korean Wedding Industry and Suggestions for Its Future Development from the Tourism Perspective", South Asian Journal of Tourism and Heritage. 6 (1), ss. 11-20.

La Ragione, T. (2019). China-Italy Destination Wedding: New Opportunities For The Luxury Tourism Market. Yayınlanmamış Yüksek Lisans Tezi, Venedik Ca' Foscari Üniversitesi, Venedik. 
Lau, C. K. ve Hui, S. H. (2010). "Selection Attributes Of Wedding Banquet Venues: An Exploratory Study Of Hong Kong Prospective Wedding Couples", International Journal of Hospitality Management, 29 (2), ss. 268-276.

Major, B., McLeay, F. ve Waine, D. (2010). "Perfect Weddings Abroad", Journal Of Vacation Marketing, 16 (3), ss. 249-262.

Nguyen, L. T. D. (2011). Marketing Mix Across Cultures: A Case Study: Binh Quoi Tourist Village's Wedding Services To France And Japan. Yayımlanmamış Yüksek Lisans Tezi, Lahtı Unıversıty Of Applied Sciences, Lahti.

Poon, A. (2009). "Prospects For The British Market 2009", Tourism Industry Intelligence, 16(1), ss. 1-4.

Ritchie, J. R. (1997). "Beacons Of Light In An Expanding Universe: An Assessment Of The State Of The Art In Tourism Marketing/Marketing Research", Journal of Travel \& Tourism Marketing, 5 (4), ss. 49-84.

Rogerson, J. M. ve Wolfaardt, Z. (2016). "Wedding Tourism İn South Africa: An Exploratory Analysis", African Journal of Hospitality, Tourism and Leisure. 4 (2), ss. 1-6.

Schumann, F. R. ve Amado, C. (2010). "Japanese Overseas Weddings In Guam: A Case Study Of Guam's First Hotel Wedding Chapel”, South Asian Journal of Tourism and Heritage, 3 (1), ss. 173-181.

Seebaluck, N. V., Munhurrun, P. R., Naidoo, P. ve Rughoonauth, P. (2015). "An Analysis Of The Push And Pull Motives For Choosing Mauritius As The Wedding Destination", Procedia-Social and Behavioral Sciences, 175, ss. 201-209.

Shone, A. ve Parry, B. (2004). Successful event management: a practical handbook. Hampshire: Cengage Learning EMEA.

Silvers, J. R. (2012). Professional event coordination, 2. Baskı, New Jersey: John Wiley \& Sons.

TDK, (2020). “Düğün” http://tdk.gov.tr/ (01.03.2020)

TUİK, (2020). "Eğitim, Kültür, Spor ve Turizm" http://www.tuik.gov.tr/UstMenu.do?metod= temelist. (01.03.2020)

Unur, K., Kanca, B., ve Ertaş, Ç. Yeni Bir Turistik Ürün Olarak Düğün Turizmi: Alanyazın İncelemesi. Uluslararası Iktisadi ve Idari Bilimler Dergisi, 3 (1), ss. 149-163.

Uysal, Ü. E. (2013). Branding İstanbul: Representations Of Religion In Promoting Tourism. Place Branding and Public Diplomacy, 9 (4), ss. 223-235.

Wolf, P., Wolf, J. ve Levine, D. (2005). Event Planning Made Easy. New York: McGraw-Hill. Liite, 1(1), 3. 